\title{
INTRAMEDULLARY TRIGEMINAL TRACTOTOMY AND ITS PLACE IN THE TREATMENT OF FACIAL PAIN
}

\author{
BY
}

\author{
MURRAY A. FALCONER \\ From Department of Neurosurgery, Otago University Medical School, \\ and Dunedin Hospital, New Zealand
}

When Sjöqvist, in 1938, introduced his operation of dividing the descending tract of the trigeminal nerve within the medulla, interest was aroused in the possibilities of an operative procedure that would abolish pain and temperature sensibility in the face, but would spare touch. During the next few years several surgeons (Rowbotham, 1938, 1939 ; Jackson and Ironside, 1939 ; Smyth, 1939 ; Walker, 1939 ; Grant and various associates, 1940 to 1943 ; Olivecrona, 1942 ; and others) attempted the new procedure, and confirmed that it produces a dissociated sensory loss. Most of these authors, however, pointed out, as did Sjöqvist himself, that the operation was difficult, and was apt to be followed by complications such as paralysis of the vocal cords, ataxia of the ipsilateral arm and of the gait, and impairment of postural sensibility in the ipsilateral limbs. Furthermore, the loss of pain sensation was often only partial and patchy, and indeed sometimes, as in two of Sjöqvist's original nine cases, no sensory loss could be discerned after operation, presumably because the incision had not been correctly placed. The operation was regarded by all as still in the experimental stage.

In an attempt to overcome these difficulties, Grant (Grant and Weinberger, $1941 \mathrm{a}, \mathrm{b}$ ) and also Olivecrona (1942), the only surgeons besides Sjöqvist to record experiences of more than two or three cases, placed the incision at lower levels in the medulla than Sjöqvist had advised. Olivecrona also advised operating under local anæsthesia so that the level and extent of the incision could be controlled by testing the patient's facial sensibility after each cut. Grant (1943), however, did not consider this practicable "since medullary section is painful, and a sudden movement of the patient at the time of section might result in disaster." Both surgeons hoped that further experience might justify their separate recommendations. However, in nine out of Olivecrona's original thirty cases of unilateral trigeminal neuralgia, the intensity of pain loss resulting from operation was negligible or only slight, while in several of these there was severe pain subsequently. Grant's (1948) experience was even more disappointing, for recently he reported that pain had occurred in five out of six patients submitted to trigeminal tractotomy for major trigeminal neuralgia, and that sensory root section of the trigeminal nerve had proved necessary for permanent relief. He has consequently lost his former enthusiasm for this procedure (Grant, 1948).

Thus most surgeons who have tried trigeminal tractotomy have been somewhat disappointed with their results. My own experience has been more gratifying, for I have now performed this procedure in twenty patients suffering from facial pain of various types, and have observed marked benefit in thirteen patients suffering from trigeminal neuralgia (tic douloureux). Technically it has proved possible in every case to produce a satisfactory level of facial analgesia, sparing touch, and with a minimum of complicating neurological sequelæ. Furthermore, my cases have now all been followed up for a sufficient period (four months to four and a half years) to show that this analgesia and the consequent relief of symptoms is generally permanent.

This paper seeks to review the anatomical and physiological basis of the operation, and to stress what appear to be the points essential to success : (1) the performance of operation under local anæsthesia ; (2) the accurate location of the descending trigeminal tract; and (3) the correct placing of the incision, which should be below that practised by Sjöqvist and more in accordance with that recommended by Grant and Weinberger (1941 a, b). 


\section{Surgical Anatomy and Physiology of the Descending Trigeminal Tract}

In order to understand the principles of the operation certain facts concerning the anatomy and physiology of the trigeminal tract must be borne in mind.

Topographical Anatomy.-The trigeminal nerve on entering the ventral surface of the pons penetrates 4 or 5 $\mathrm{mm}$. through the middle cerebellar peduncle (brachium pontis), and then in the lateral portion of the tegmentum it breaks up into ascending and descending fibres. The latter form the descending tract (Fig. 1). As the

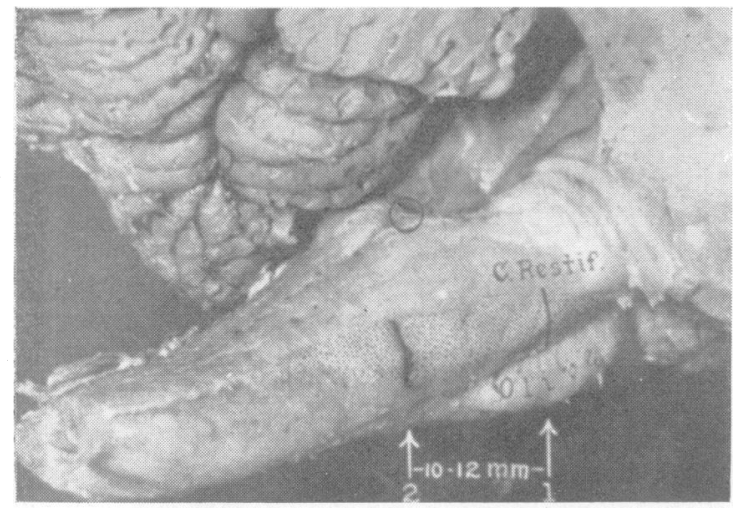

FIG. 1.-Prepared specimen of brain stem taken from Grant and Weinberger (1941 b) shows course of descending trigeminal tract (in stipple). The lower half of the right cerebellar hemisphere has been removed to show the fourth ventricle with its lower angle or obex (marked by a small circle). The sites of two incisions are shown: the upper (1) is at the level recommended by Sjöqvist ; the lower (2) at that recommended by Grant and Weinberger. The situation of Olivecrona's incision (not shown) lies midway between these two.

descending tract proceeds downwards it becomes more and more superficially placed, and at the level of the middle of the olive (that is, 8 to $10 \mathrm{~mm}$. cephalic to the lower end of the fourth ventricle), it is covered dorsally and laterally by only the restiform body (Fig. 2a). This is the level at which Sjöqvist (1938 a, b) sectioned the tract, but inevitably section at this level must damage part of the restiform body. Further down its course, just below the fourth ventricle, the tract emerges on the dorso-lateral surface of the medulla, where it forms a well-defined eminence known as the tuberculum cinereum or rolandic tubercle.

At the level of the obex or lower angle of the fourth ventricle (Fig. 2b) the descending tract has not quite emerged from under cover of the fibres of the dorsal spino-cerebellar tract, which however at this situation are running almost at right angles to the longitudinal axis of the brain stem to enter the lower part of the restiform body (Sabin, 1901). This is the level at which

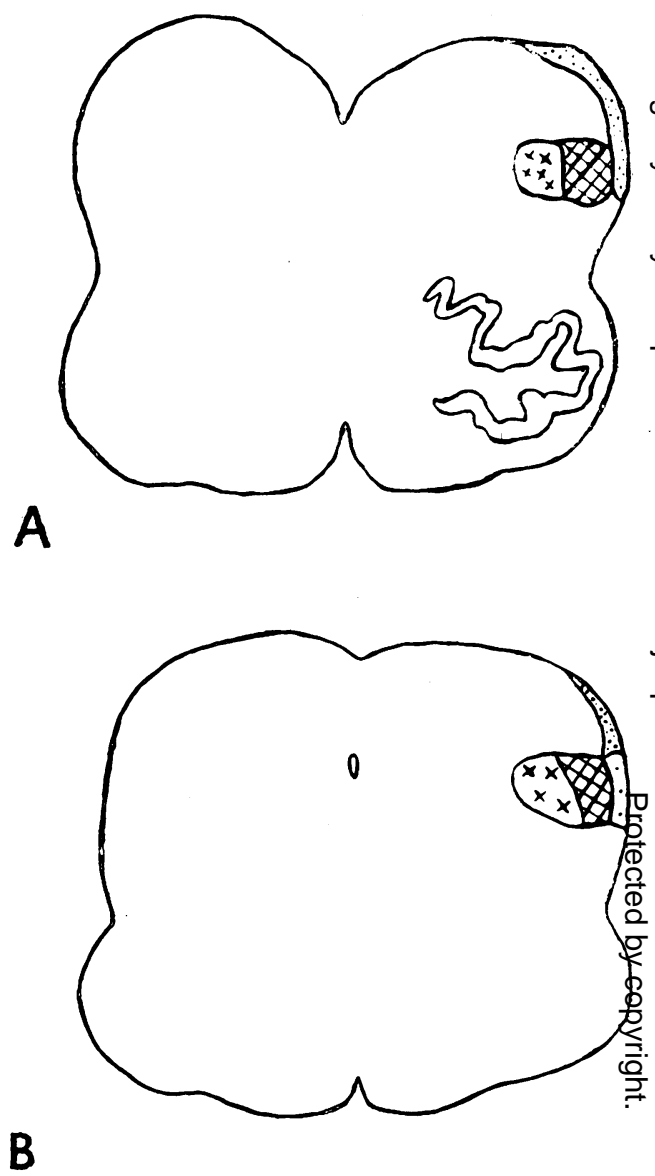

Fig. 2.-Cross-sections of medulla $(\times 4)$ show relative positions of descending trigeminal tract (cross $=$. hatching), its nucleus (crosses), restiform bod N (close dots), and dorsal spinocerebellar tract (sparse dots); (a) shows the relationships at the level of the middle of the olive, $(b)$ at the level of the obex, and (c) at a level $4 \mathrm{~mm}$. below the obex. 

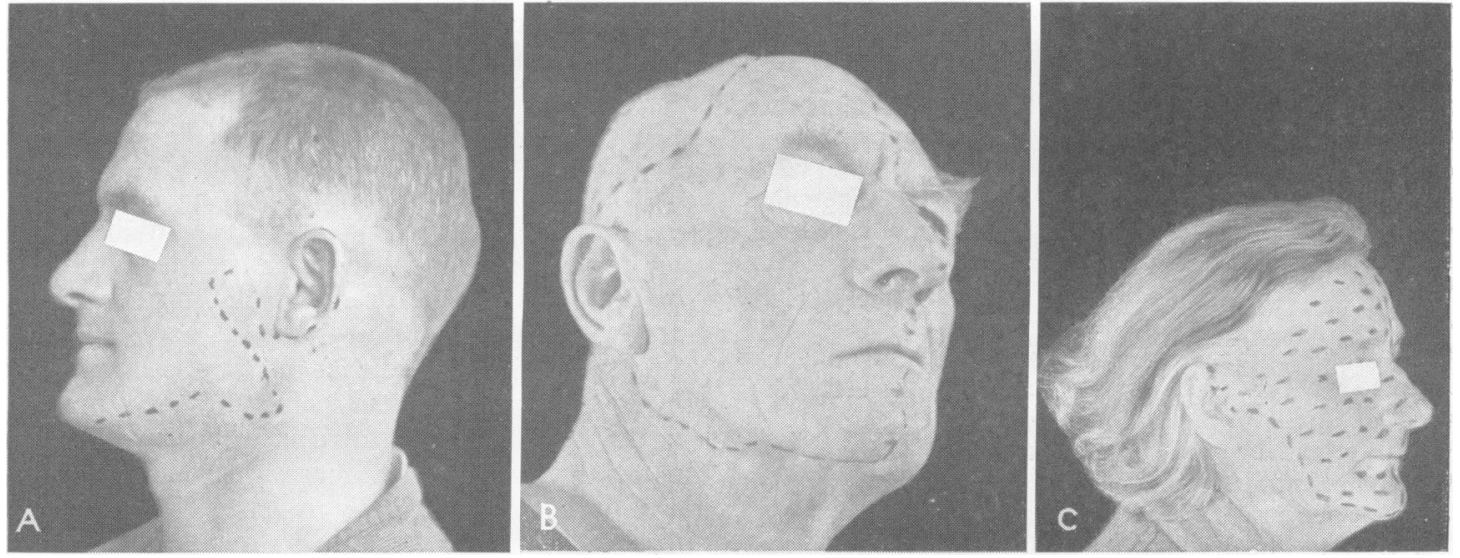

FIG. 3.-Postoperative photographs of three patients showing variations in loss of pain sensibility: (a) Case $3,(b)$ Case 5, and (c) Case 13.

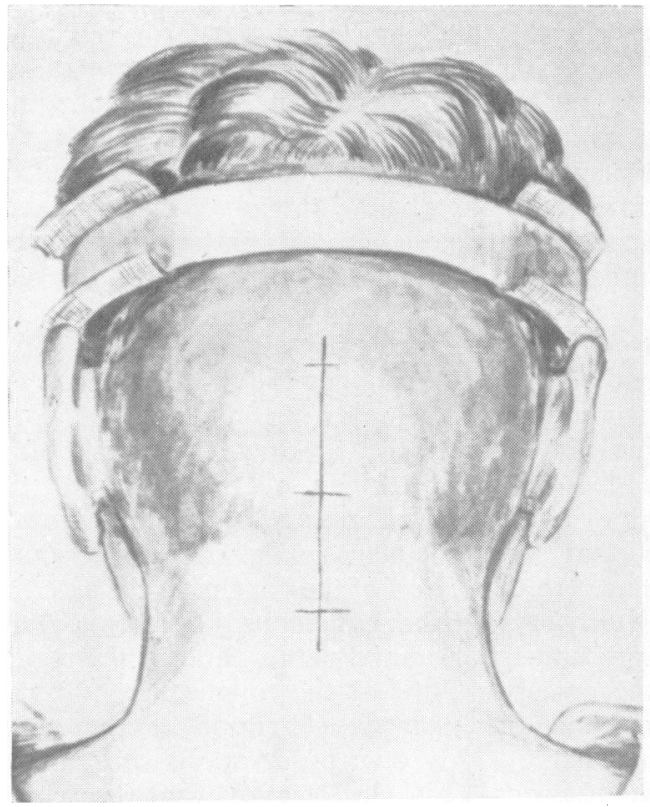

FIG. 4.-.-Line of incision (From Olivecrona, 1942)

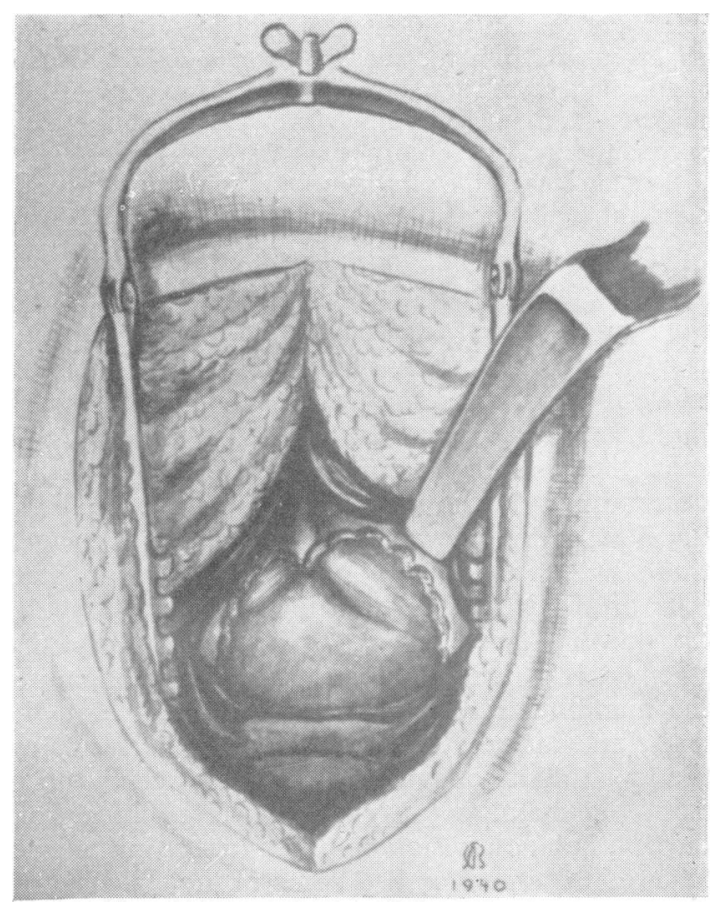

FiG. 5.- Size and form of bone defect in a case of rightsided tractotomy (From Olivecrona, 1942). 
Olivecrona (1942) recommended section, and section of the descending tract here may avoid the restiform body, and also spare many of the fibres of the dorsal spinocerebellar tract, because these are running parallel to the incision.

At a level 4 to $5 \mathrm{~mm}$. below the obex the descending tract occupies the dorso-lateral border of the medulla and is covered only by a few sparse external arcuate fibres (Fig. 2c). This level is that recommended for section by Grant and Weinberger (1941 a, b), and corresponds approximately to the centre of the tuberculum cinereum. At this level the descending tract has wound slightly backwards so that it occupies the dorso-lateral border of the medulla. Medially to it lies the fasciculus cuneatus, while at its anterior margin is the fissure through which emerge the bulbar rootlets of the spinal accessory nerve. The dorsal situation of the descending tract at this level facilitates the operative approach, for the tract can be readily transfixed by a guarded knife inserted from behind in a postero-anterior direction, and not obliquely as is necessary at higher levels.

Below the tuberculum cinereum the descending tract sinks into the substance of the spinal cord and becomes continuous with the marginal fasciculus of Lissauer.

Nucleus of the Descending Root.-Throughout its course the nucleus of the sensory root lies on the medial and deep aspect of the tract. It must be clearly understood that the fibres in the descending tract belong to the primary order of sensory neurones, for they are the axones of cells in the Gasserian ganglion (and also to a slight extent from the sensory ganglia of the seventh, ninth, and tenth cranial nerves). The cells in the nucleus of the sensory tract, however, belong to the secondary order of sensory neurones.

The nucleus of the sensory root is continuous with the substantia gelatinosa of Rolando of the spinal cord.

Types, Arrangement, and Function of Fibres in the Sensory Tract.-It would seem that the descending tract subserves pain and temperature sensibility not only from the fifth, but also from the seventh, ninth, and tenth cranial nerves. Also it would seem that there is a lamination of fibres within the descending tract, so that fibres from the ophthalmic division lie in the ventro-lateral part of the tract, those from the maxillary division in the intermediate part of the tract, and those from the mandibular division in the dorso-medial part of the tract. Further, it would seem that the fibres belonging to the mandibular division are the first to leave the tract, and that they start to do so at or just below the level of the obex ; they are followed by fibres from the maxillary division, whereas fibres from the ophthalmic division continue lowest in the tract towards the spinal cord. Some of the evidence for these various conclusions will be considered.

Sjöqvist (1938) carried out a " fibre analysis" of the sensory root, and showed that it is composed almost exclusively of fibres less than $5 \mu$ in diamete $\stackrel{\mathbb{D}}{=}$ Fibres of such small dimensions had been show earlier by Zotterman and others to be responsible for conveying pain and temperature impulses, whereas fibres conveying muscle sense, touch, and pressure sense are all of larger calibre. Sjöqvis巳 therefore, argued that the descending tract must. mediate pain and temperature sensibility, a cons clusion which had already been deduced from: observations on the clinical effects of posteriof inferior cerebellar artery thrombosis (Wallenberg syndrome), and which since has been established b the abolition of these sensory modalities observe after successful section of the tract.

Sjöqvist also showed that the cross-sectional ares of the descending tract remains fairly uniform untif the lower pole of the olive is reached (this is just below the level of the obex), but that below this level it decreases rapidly in size. That the firs? fibres to leave the tract do so on its dorso-media border and come from the mandibular division has been suggested by many authorities, and alsio by my own observations on the effects of systematic ally sectioning the tract at varying levels in patients under local anæsthesia. Thus I have found that whereas at a level of $4 \mathrm{~mm}$. or so below the o\&ex one can readily denervate the upper two divisions of the face, the lower division may be difficule th denervate at this level. Instead, in order 8 th

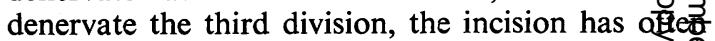
to be made at or slightly below the level of athe obex, and has to be carried into the dorso-mediad part of the tract. I would however qualify this statement by adding that sometimes an incision as low as $4 \mathrm{~mm}$. below the obex has produce satisfactory analgesia in all parts of the face. Weinberger and Grant (1943) have also observed this.

Brodal (1947) first drew attention to the full extent of the analgesia that follows section of the descending tract. Sjöqvist in his original com munication reported that the area of analgesia ofter extended below the angle of the jaw into the territory of the cervical plexus, but Brodal showe also that a dissociated analgesia is frequentip produced in the region of the concha of the externa ear (territory of the cutaneous branches of the seventh and tenth cranial nerves) and in the regiog of the posterior third of the tongue, the tonsillar fossa, and the pharynx (territory of the nint cranial nerve). My own observations substantiate those of Brodal (Fig. 3a, b, c). From the phyloe. genetic point of view this is in accordance with thes tendency noted elsewhere in the central nervous system for fibres conveying the same type of impulse to pass to the same nucleus. 


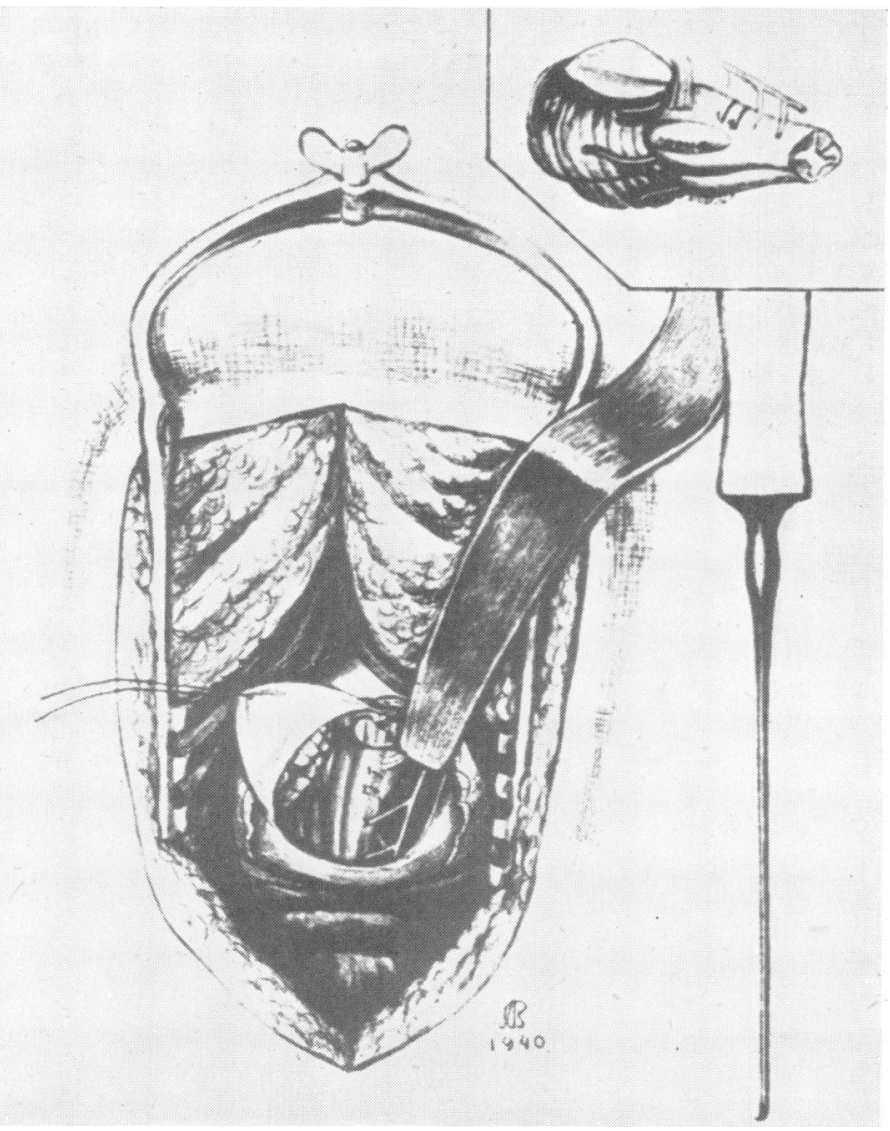

FIG. 6.-Level of incision into the medulla: (1) indicates site of Sjöqvist's original incision, (2) site of Olivecrona's incision. Recommended site is $4 \mathrm{~mm}$. below (2). (From Olivecrona, 1942).

the atlas is divided with the diathermy needle. After a sufficient area of bone has been exposed two burr holes are made. The subsequent nibbling away of bone is much facilitated if two burr holes, instead of the customary single one, are made. Bone is then rongeured away until a sufficient area of dura is exposed (Fig. 5). The posterior rim of the foramen magnum is of course removed. The dura is then opened by a V-shaped incision (Fig. 6). The occipital sinus may occasionally be large, but hæmorrhage from this source can always be controlled by silver clips. After incising the arachnoid and evacuating the fluid in the posterior cistern, the tonsil on the side of operation is gently elevated and a suitable point for incision into the spinal trigeminal tract selected."

Selection of Site for Incision.-Like Olivecrona, the principal landmark we seek is the obex or lower end of the fourth ventricle. Usually this is readily found, and at the same time a good view of the foramen of Magendie is obtained. Occasionally, however, a loop of a posterior inferior cerebellar artery runs across this particular part of the field and may have to be displaced before the obex is clearly seen. In one case, attempted after my first twenty cases, the lower end of the fourth ventricle

\section{Technique of Operation}

In all except two of my first twenty cases the operative approach up to and including the section of the medulla was performed under local anæsthesia employing 1 per cent. procaine solution. Preliminary medication has usually been with morphine sulphate gr. $1 / 6$ and hyoscine hydrobromide gr. $1 / 100$ or $1 / 150$ given hypodermically.

Each patient has been operated on in the prone position, and the surgical exposure outlined by Olivecrona (1942) has been followed. In Olivecrona's words the steps of this exposure are as follows.

"A straight incision is made from a point just below the occipital protuberance to the spinous process of the third cervical vertebra (Fig. 4). The soft parts are divided exactly in the midline. The insertions of the short rotators of the head are freed from the occipital bone and their origin on was occluded by a stout imperforate septum without trace of a foramen of Magendie, and the operation had to be abandoned because a suitable landmark could not be found. This, however, has happened only once in twenty-four operations.

The second landmark is the line of emergence of the bulbar rootiets of the spinal accessory nerve on the lateral aspect of the medulla. This marks the line of the ventrolateral border of the descending tract. The rootlets are not contiguous, like the rootlets of the vagus nerve, but are separated from one another. Sometimes they are hidden by the vertebral artery as it runs vertically upwards lateral to the medulla, and then the landmark may be only approximately placed.

Once the obex has been identified, the locating of the descending tract is not difficult. Sometimes the tuberculum cinereum can be discerned as an eminence lying below and lateral to the obex along 
the dorso-lateral border of the medulla, but more often no definite eminence is discernible. In this event some tiny vascular marking is noted on the dorsal surface of the medulla at a level approximately $4 \mathrm{~mm}$. below the obex, and then, with this marking as a guide to the transverse level of the incision, the posterior surface of the medulla lateral to the midline is divided into equal lateral and medial portions. The lateral portion thus located, including the dorso-lateral border of the medulla, usually corresponds with the course of the descending tract.

Verification of Correct Site for Incision.-Until recently $I$ used to incise the medulla at the site so marked, and could afterwards tell from the result how accurate was my trial incision and whether it required extending. Now I use a straight surgical needle mounted on a long handle, and I first prick the medulla to depths of about $3 \mathrm{~mm}$. along the line of the proposed incision in order to verify the position of the descending tract. For, as the descending tract is pierced, slight momentary pain is felt in the appropriate part of the face. In this way the situation of the descending tract can be mapped out accurately before the incision is made.

The actual incising of the tract is done with a straight tenotomy knife. This is inserted transversely to a depth of $3 \mathrm{~mm}$. along the dorso-medial border of the tract, and is then directed outwards so as to emerge on the surface of the medulla along the ventro-lateral border of the tract (here marked by the line of the bulbar rootlets of the spinal accessory nerve). The incision if correctly placed is .very painful, although not quite as painful as section of a posterior nerve root. The pain, however, is momentary, and it is itself a guide to a satisfactory incision, for unless pain is severe a satisfactory loss of pain sensibility cannot be expected. Some of our patients have screamed at this stage ; but, probably because we have always warned them beforehand, none has shifted his position on the operating table. As soon as the momentary pain is over, the anæsthetist checks pain sensibility in the face, and reports on the extent and degree of analgesia. If this is patchy, the incision is extended. Owing to the toughness of the arachnoid it is impossible to complete the incision in one stroke. Therefore two and even three strokes are normally required to complete the incision, and for one of these secondary cuts I have usually employed a $3 \mathrm{~mm}$. fragment of safety-razor blade set at right angles in the tip of an artery forceps (Fig. 7). This I have inserted at the ventrolateral border of the tract, and then cut backwards.

As my experience has grown, I have become accustomed to placing the incision accurately $\stackrel{\mathcal{D}}{\text { at }}$ at $_{\text {and }}$ the first trial, and to securing prompt analgegia over the side of the face. In some of my earfier cases I was not so fortunate, and it was from these cases that I learnt about the lamination of fibmes within the descending root. It is easier in this operation to denervate the upper two divisions than the lower division, and an incision into the dors:

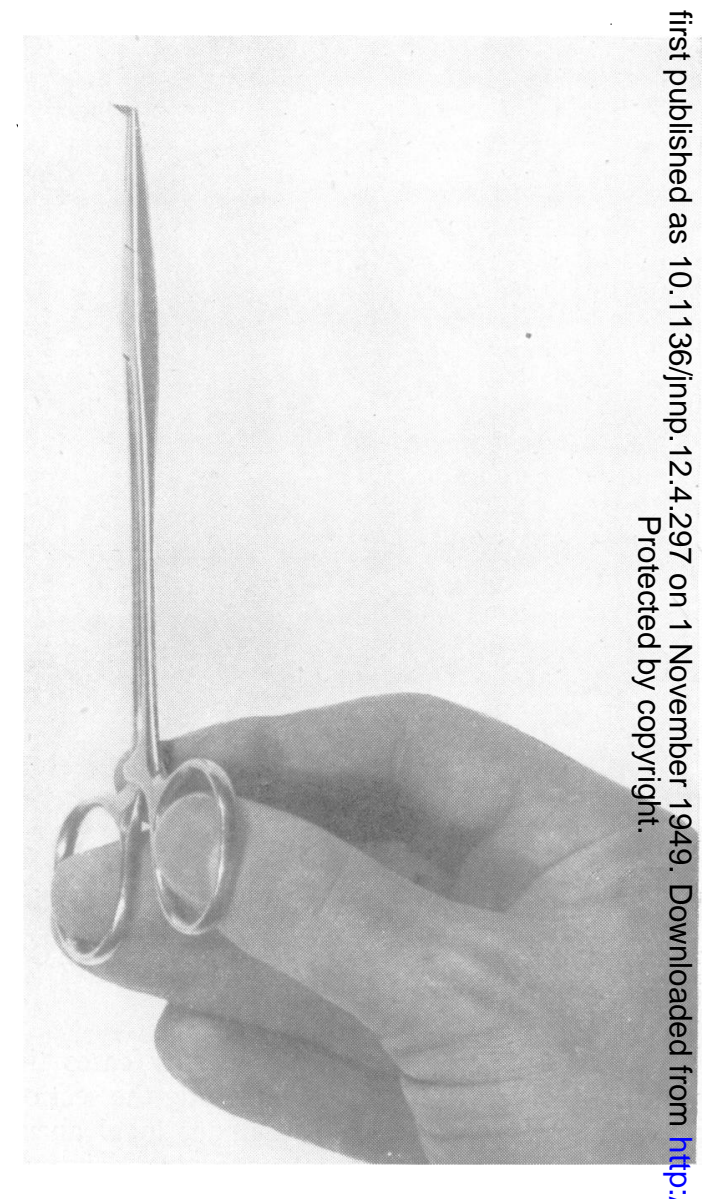

FIG. 7.-Fragment of razor-blade set in tip of artery forceps used in making the incision.

lateral border of the medulla at a level $4 \mathrm{~mm}$. be the obex will generally produce analgesia over the forehead and cheek, and often over the third divisqon as well. If by any chance the ophthalmic division is spared by the first stroke, the incision should Bbe extended in a ventro-lateral direction. If, however, the mandibular division is spared and analgesiaof this division is required, the original incision may be extended with great caution dorsally to the mid-point between the dorso-lateral border of the medulla and the midline, but generally it is prefor- 
able to make a fresh incision at a higher level (say opposite the obex). In no circumstances, if an incision is a failure, should it be deepened to more than $3 \mathrm{~mm}$., but instead a new incision should be made either higher or lower, and it is astonishing how often at a new level only 2 or $3 \mathrm{~mm}$. away a satisfactory result may be forthcoming.

Usually the incision into the medulla is bloodless, but sometimes bleeding occurs and necessitates the application of a muscle pledglet. If a tiny arterial twig crosses the line of the proposed incision, I do not hesitate to coagulate it with a diathermy current applied through a slender hook before making the incision.

Closure.-Once a satisfactory degree of analgesia has been obtained our patients have usually been given an intravenous pentothal anæsthesia and the closure has been made under this. The incision in the dura is sutured as neatly as possible, and the occipital muscles closed in layers.

Postoperative Course.-Our usual programme has been to keep the patient in bed for ten days before allowing him up. Generally daily lumbar punctures are performed, and 10 to $20 \mathrm{ml}$. of cerebrospinal fluid are drained off until the lumbar puncture pressure returns to normal and there are less than 50 white cells per c.mm. in the cerebrospinal fluid. This usually takes a week, and in this way we believe we guard against the development of an aseptic leptomeningitis (Finlayson and Penfield, 1941). Our patients have usually left hospital within sixteen to twenty days, and returned to work within two to three months.

\section{Comments on the Operative Procedure}

The operative steps described above are identical with those described by Olivecrona (1942), except as regards the placing of the incision and the method of determining the precise situation of the tract by needling before sectioning it. The essential points in the operation are :

1. Performance under Local Anæsthesia.-Olivecrona (1942) seems to have been the only surgeon to recommend local anæsthesia for this procedure. Sjöqvist (1938) and those who have followed his technique, including Grant and his various associates (1940 to 1943), have all performed trigeminal tractotomy under general anæsthesia in order to avoid the pain inseparable from section of the tract. Even under light inhalational anæsthesia Sjöqvist has noted that patients may wince when the tract is being cut. It is of course impossible in such circumstances to define the position of the descending tract by pricking the medulla, and, more important still, to test the patient's facial sensibility after each cut. The chances of an unsatisfactory technical result are therefore increased.

My experience has been that the operation usuaily can be performed under local anæsthesia. I was able to do so satisfactorily in eighteen of my twenty cases. In one case (Case 20) in which operation was begun under local anæsthesia, an intravenous anæsthetic became necessary at an early stage because of the patient's restlessness and anguish; and in this case a second craniotomy (also under general anæsthesia) proved necessary a few days later because the incisions made at the first operation had severed only part of the tract. In the other case (Case 18) operated on under general anæsthesia, the patient previously had had more than ten operations for lupous ulcers of the face performed by plastic surgeons, all under general anæsthesia, and she obviously would not have tolerated local anæsthesia alone.

2. Midline Occipital Craniotomy.-This is simpler and easier to perform than the unilateral cerebellar exposure employing a curved incision used by Sjöqvist (1938) and those who have followed his lead. At the level in the medulla which Sjöqvist favoured, it was necessary when incising the tract to approach the medulla on its lateral aspect, and the removal of bone laterally over the appropriate cerebellar hemisphere facilitates this. However, when the incision is made at levels below the obex, the point of the knife can be inserted into the medulla directly from behind, and there is no need for a wide craniotomy.

It is unnecessary to remove the arch of the atlas vertebra in either the Sjöqvist or the Olivecrona approach.

3. Locating the Descending Tract.-It is easier to locate the position of the descending tract at or below the level of the obex than at a higher level, for less retraction of the cerebellar tonsil is required. Moreover, with the lower cut the vagus rootlets and the olivary eminence need not be exposed.

The method of confirming the location of the descending tract by pricking the medulla has so far been tried by me in only a few cases, but it has proved helpful.

4. Level of Section of Tract.-At a level $4 \mathrm{~mm}$. or so below the obex it is possible to produce a satisfactory degree of analgesia in most cases, particularly in the first and second trigeminal divisions, and sometimes also in the third division. Furthermore, because the tract is superficial at this level, the risk of damage to neighbouring structures such as the restiform body is minimized, and injury to 
the vagus nerve, a risk ever present in the Sjöqvist procedure, is completely avoided.

5. Testing Analgesia after each Cut in the Medulla.-This of course has to be done by some doctor outside the operating team. The incision is considered satisfactorily placed only when the patient can no longer discriminate between the blunt and the sharp end of a pin over that part of the face where pain was complained of spontaneously. In most instances this has been the first division (vide infra).

6. Subsequent Incision if First is Unsatisfactory.If, at operation, complete analgesia is not forthcoming after an incision which seems to be correctly placed, a second incision should be made at another level, as mentioned in the preceding section. Again if, a few days after operation, sensory testing shows that pain loss, which seemed complete while the patient was on the operating table, has disappeared or become patchy, the operative area should be reopened. Then, depending on the pattern of sensory change, the original incision should be extended or another made at a different level. In my series of twenty cases reopening of the craniotomy had to be undertaken in three.

7. Operative Risks.-Trigeminal tractotomy carries the same risks as a suboccipital craniotomy for such elective procedures as intracranial section of the eighth or ninth cranial nerves. In skilled hands the operative mortality should be low. In my series of twenty cases there was one death from extradural clot compression, and in this patient symptoms came on suddenly on the fifth postoperative day. Post-mortem examination indicated that death in this case could have been prevented, had the nature of the complication been recognized in time and the operative area reopened. The relevant points of the history follow :

Case 4: Death on Fifth Postoperative Day from Extradural Clot Compression.-In a 57-year-old woman suffering from post-herpetic neuralgia of the upper trigeminal division, trigeminal tractotomy was carried out without undue difficulty. For the first five days after operation she seemed to be progressing satisfactorily. She was free from her pain and had little headache. Lumbar punctures repeated daily showed pressures of under $\mathbf{2 0 0} \mathrm{mm}$., and the cerebrospinal fluid, which had been moderately bloodstained, seemed by the fifth day to be clearing.

She was placed in a room by herself, and after she had eaten a good lunch on the fifth postoperative day she told the nurse she felt all right, and so was left alone for a post-prandial nap. When seen an hour later she appeared to be sleeping, and so was not disturbed. Two hours later, however, her respirations were found to be slow and laboured, and she could not be roused. $\overline{\text { Bber }}$ lower limbs would move in response to painful stinânili but not her upper limbs. The tendon jerks were c]epressed. The pupils were small and equal, and plantar responses both extensor. Lumbar puncture showesf a fairly clear cerebrospinal fluid under a pressure of only $20 \mathrm{~mm}$. Blood pressure was unaltered at about 170 $\mathrm{mm}$. Hg. It was thought she must have had " apoplectic stroke."

She died about three hours later, developing pyrefia in the terminal stages. At necropsy a large extradīifal clot was found beneath the muscles and indenting the dura of the posterior fossa. It was firm and friable, apd was considered by the pathologist (the late Dr. John Sutherland) to have been present for several days. O1t was unfortunate that the nature of her coma had frot been interpreted correctly, for re-exploration with removal of this clot would probably have saved her life. We were misled by the fact that before the sudden lass of consciousness she had appeared to be progressig well and had not complained of any untoward symptoms. Yet the post-mortem examination showed that the $\$+\$$ had probably been there from the time of her operatiph.

\section{Case-Material and Results of Operation 0 i}

Between August 1944 and March 1949, i î̉trdmedullary trigeminal tractotomy has been performid by me in twenty patients, including one who intwo separate sessions had the operation performed on both sides for bilateral trigeminal neuralgia. The patients included examples of the following difforest conditions: (a) unilateral trigeminal neuralga (eleven patients, all relieved); (b) bilaterab txigeminal neuralgia (two patients, both relieved (c) "syndrome of painful anæsthesia" following complete section of the sensory root of the towgeminal nerve performed for trigeminal neuralsa (two patients, both improved); (d) postherpegic neuralgia affecting the face (four patients : ofe died, and none benefited); (e) causalgia of face secondary to lupus (one patient, not benefited). $\overrightarrow{\hat{0}}$

Twelve of these twenty patients were males and eight were females. Their ages varied from 34 to 70 years, with two patients in the fourth decale of life, three in the fifth, seven in the sixth, five in seventh, and three over seventy years of age. There was one death occurring in hospital (mortality rate 5 per cent.). Two patients have since died 3 of unrelated causes, and the surviving patients haye been followed up for periods up to four and a helf years. All patients except one have been examined personally by me at some stage after their dischakge from hospital, but in most instances the mare recent follow-up enquiries have been carried $\overrightarrow{\mathrm{g}} \mathrm{t}$ by letter to the patient or his doctor. The clinieal features of each patient are summarized in the Table. 
The results achieved will be studied, firstly as regards the physiological effects of the operation, and secondly as regards its therapeutic benefits.

\section{Physiological Effects of Operation}

In all cases (excluding of course the first two cases in the series, because, as the result of a previous sensory root section, they already exhibited complete cutaneous sensory loss) a satisfactory loss of pain sensibility was produced in the face, usually with complete sparing of touch but with loss of temperature sensibility. Moreover in all instances this loss of pain sensibility appears to have been permanent. Generally the degree of pain loss was complete even to heavy pin prick over all three divisions of the trigeminal nerve. In four cases (Cases 5, 7, 13, 16), however, it was complete in the upper part of the face but incomplete in the third division.

In most cases the area of pain and temperature loss extended beyond the territory of the trigeminal nerve. For instance, analgesia was often noted around the angle of the jaw which is in the territory of the cervical plexus. With one exception, whenever sensation was deliberately tested in the region of the concha of the ear (seventh and tenth cranial nerves), and of the tonsillar fossa, pharynx, and soft palate (ninth cranial nerve), analgesia with sparing of touch was noted in these areas. Unfortunately not until I had read Brodal's (1947) paper was I made aware that these areas are commonly involved, and several patients consequently have not been examined in this respect.

In most cases the sensation of touch as tested with a cotton-wool wisp, appeared to have been completely spared. As after chordotomy, however, the sensation of touch becomes bereft of any concomitant feeling of tickle, and some patients will notice the difference. In a few patients, however, a slight but definite impairment of tactile sensibility appeared to be present. Weinberger and Grant (1942) considered that touch was frequently impaired, but Sjöqvist (1938) and Smyth (1939) did not find this.

In all cases pain sensitivity was lost in the cornea, although a feeling of touch remained. The corneal reflex was usually greatly diminished and sometimes seemed almost absent. In no instance did any signs of neuropathic keratitis develop subsequently, nor were any special precautions taken to avoid this complication.

In six cases slight but permanent ataxia has persisted after operation, but this is the only undesirable neurological complication noted in this series, and in no instance has it been disturbing. Several patients exhibited ataxia in the immediate postoperative stage, but this soon disappeared.
No case developed laryngeal palsy nor any loss of postural sensibility in either arm or leg. There was no instance of masticatory paralysis.

The only other complication seen in this series was a herpetic eruption, usually in the upper or lower lip, but sometimes in the forehead. This occurred in about half the cases and appeared between the second and sixth postoperative days. In every respect the eruption was similar to that so commonly seen after section of the sensory root of the Gasserian ganglion, and likewise proved temporary.

The physiological effects of intramedullary tractotomy were thus uniformly gratifying in my series. There was no case in which a satisfactory loss of pain sensibility was not produced in the face. In this respect, therefore, the results achieved in this series of cases are superior to those recorded by previous authors, but before these results were attained a second or even third incision at a slightly different level had to be made in the medulla in thirteen cases; in three cases a second operation proved necessary to complete the incisions.

\section{Therapeutic Effects of the Operation}

In Trigeminal Neuralgia.-Observations in this series confirm previous reports that benefit from this operation is principally in the field of trigeminal neuralgia. Permanent benefit was seen in eleven cases of unilateral trigeminal neuralgia, and in two cases of bilateral trigeminal neuralgia. Many of my patients were elderly and retired, but all those who were operated upon while still in the period of their active working life have since returned to their normal occupations.

With one exception all the patients with unilateral trigeminal neuralgia suffered from pain in the first or second divisions of the nerve. The exception (Case 14) was a man with third-division as well as second-division pain, who already had a complete and permanent facial palsy and consequently ran an almost certain risk of neuropathic keratitis if his cornea were completely denervated. The operation proved successful and, although the cornea was rendered analgesic, touch was present in it and he has not had trouble with his eye. In another case (Case 5) with exceptionally violent trigeminal neuralgia, the pain had originated in the third division, but during the particular attack which caused his referral for operative treatment the pain spread over the side of his face. The tractotomy relieved pain in the first two divisions, but a partial sensory root section was subsequently required to ease the pain in the third division.

All patients with unilateral trigeminal neuralgia when followed up expressed themselves as very 
TABLE.-PARTICULARS OF CASEZৃTREATED

A. CASES OF PERSISTENT PAIN FOLLOWING COMPLETE SECTIO OF SENSOI

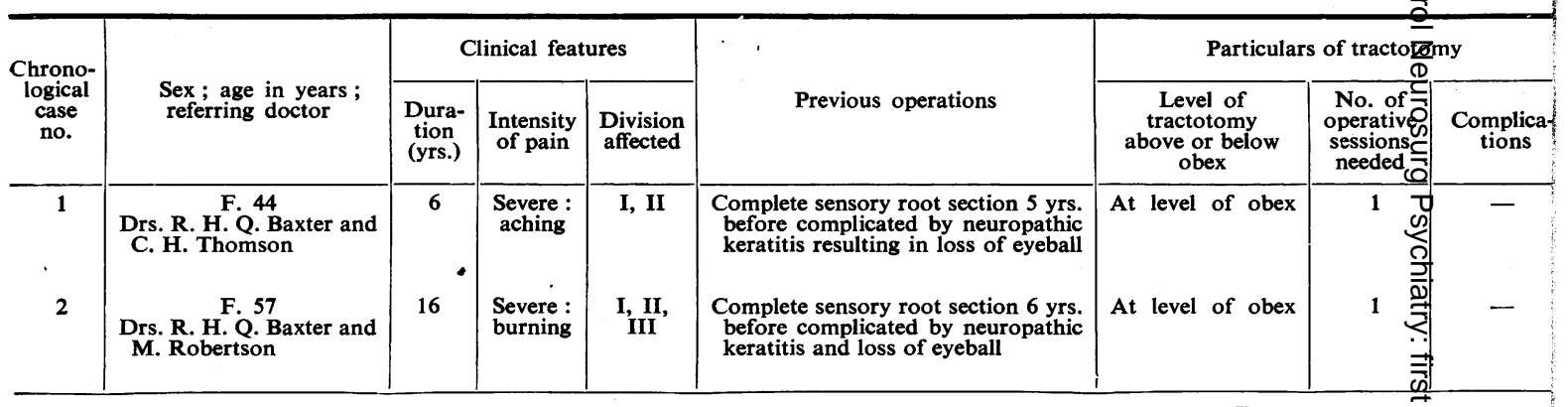

B. CASES OF POST-HERPET

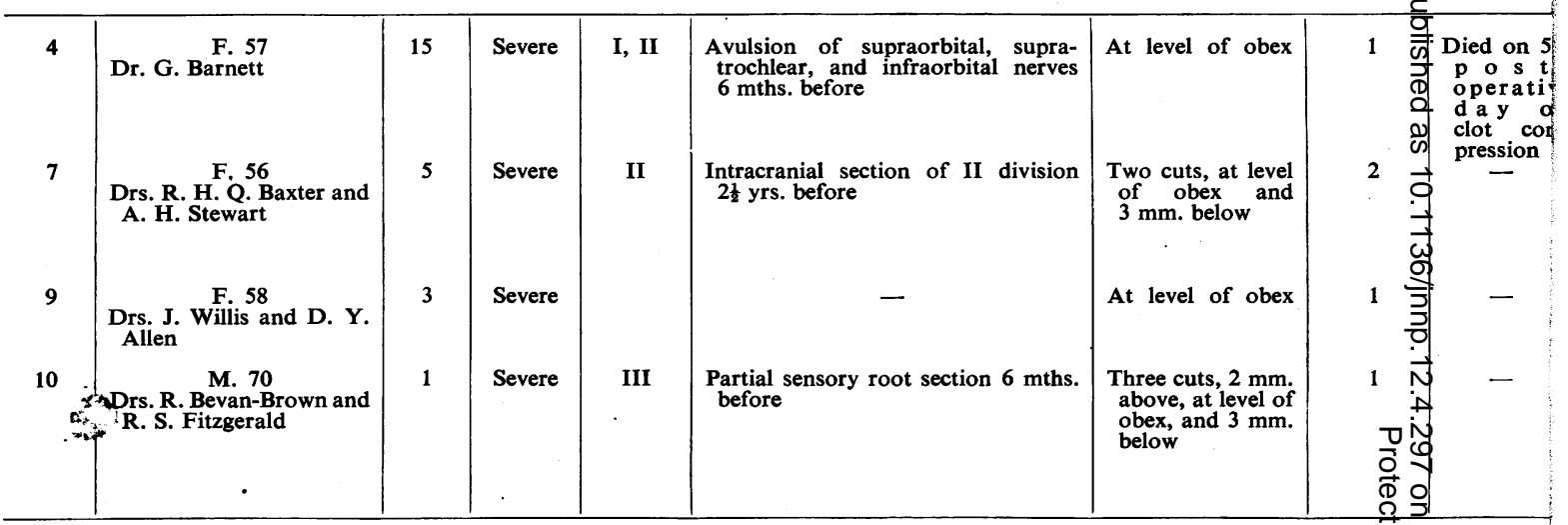

C. CASES Q

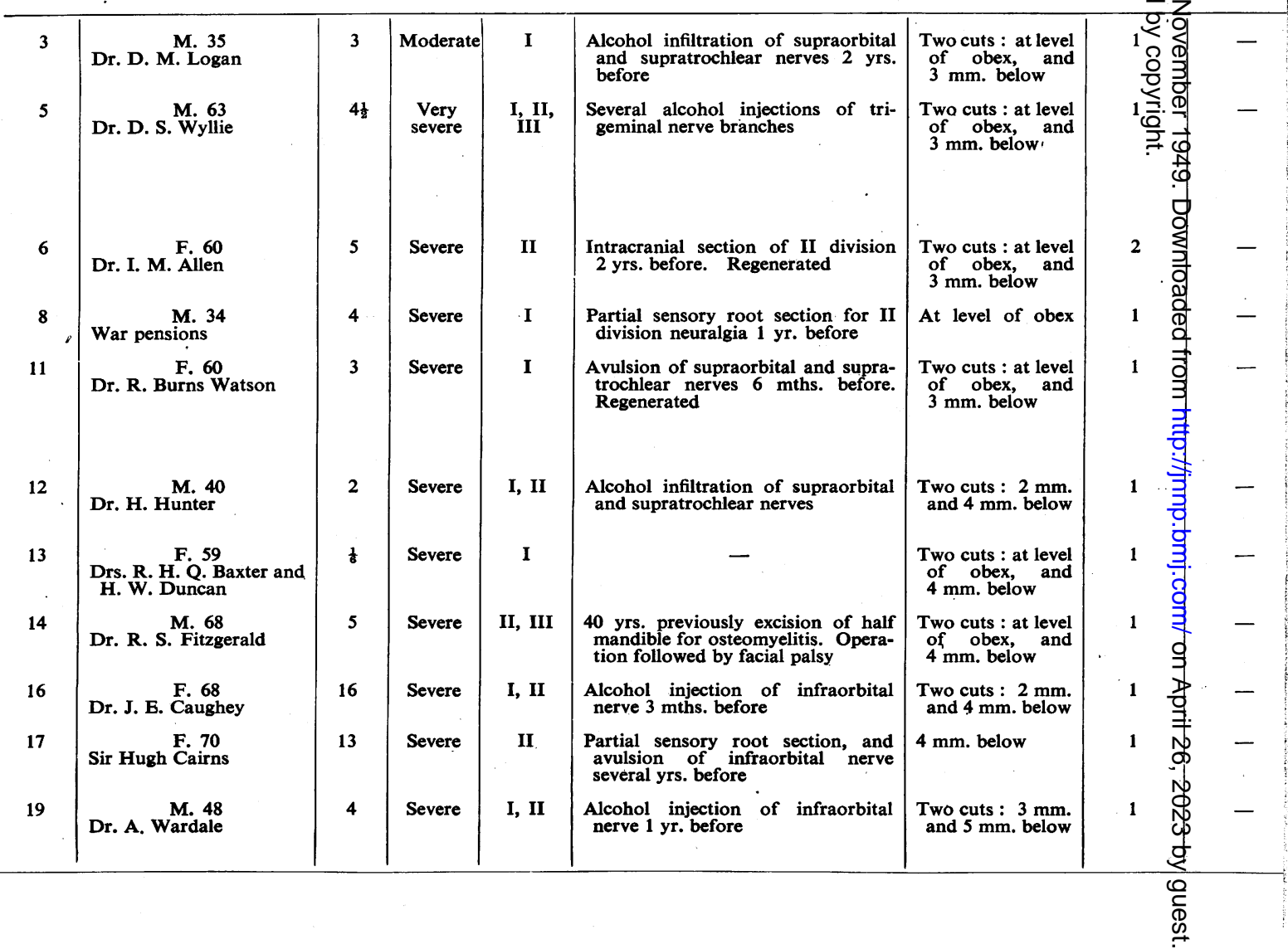


ITRAMEDULLARY TRIGEMINAL TRACTOTOMY

JOT OF TRIGEMINAL NERVE PERFORMED FOR TRIGEMINAL NEURALGIA

\begin{tabular}{|c|c|c|c|c|c|c|c|c|}
\hline \multicolumn{3}{|c|}{$\begin{array}{c}\text { Distribution and grade of analgesia } \\
\text { after tractotomy }\end{array}$} & \multirow{2}{*}{$\begin{array}{l}\text { Period } \\
\text { of } \\
\text { follow- } \\
\text { up after } \\
\text { tracto- } \\
\text { tomy } \\
\text { (yrs.) }\end{array}$} & \multicolumn{4}{|c|}{ Follow-up results } & \multirow{2}{*}{$\begin{array}{l}\text { General impression } \\
\text { of end-result }\end{array}$} \\
\hline $\begin{array}{l}\text { rigeminal nerve division } \\
\begin{array}{ccc}\text { I } & \text { II } & \text { III }\end{array}\end{array}$ & $\begin{array}{c}\text { 9th } \\
\text { cranial } \\
\text { nerve }\end{array}$ & $\begin{array}{l}\text { 10th } \\
\text { cranial } \\
\text { nerve }\end{array}$ & & $\begin{array}{l}\text { Persistent or } \\
\text { recurrent pain }\end{array}$ & $\begin{array}{l}\text { Paræsthesias } \\
\text { of face }\end{array}$ & $\begin{array}{c}\text { Other neurological } \\
\text { sequelæ }\end{array}$ & $\begin{array}{c}\text { Further operative } \\
\text { procedures } \\
\text { required }\end{array}$ & \\
\hline $\begin{array}{l}\text { Complete analgesia } \\
\text { already present before } \\
\text { tractotomy }\end{array}$ & $?$ & $?$ & $4 \frac{1}{2}$ & $\begin{array}{l}\text { Pain disappeared } \\
\text { from forehead, } \\
\text { but still present } \\
\text { in socket of eye }\end{array}$ & 一 & $\begin{array}{l}\text { Slight ataxia of } \\
\text { ipsilateral upper } \\
\text { limb }\end{array}$ & - & $\begin{array}{cr}\text { Improved. } & \begin{array}{r}\text { Re- } \\
\text { com- }\end{array} \\
\text { mitted } & \text { suicide, } \\
? \text { due to other }\end{array}$ \\
\hline $\begin{array}{l}\text { Complete analgesia } \\
\text { already present before } \\
\text { tractotomy }\end{array}$ & $?$ & $?$ & $4 \frac{1}{2}$ & $\begin{array}{l}\text { Still pain in all } \\
\text { three divisions, } \\
\text { but less severe } \\
\text { than before }\end{array}$ & 一 & - & 一 & Improved \\
\hline
\end{tabular}

RIGEMINAL NEURALGIA

\begin{tabular}{|c|c|c|c|c|c|c|c|c|c|}
\hline+ & + & + & $?$ & $?$ & - & - & - & - & - - \\
\hline+ & + & \pm & + & + & $3 \frac{1}{2}$ & $\begin{array}{l}\text { Pain disappeared } \\
\text { te m or a rily, } \\
\text { then recurred } \\
\text { spreading into } \\
\text { III division }\end{array}$ & 一 & - & - \\
\hline+ & + & + & + & + & 3 & $\begin{array}{l}\text { Pain lessened for } \\
6 \text { mths., then } \\
\text { recurred }\end{array}$ & - & - & 一 \\
\hline+ & $1+$ & + & + & \pm & $2 \frac{1}{2}$ & Pain not altered & - ' & - & $\begin{array}{l}2 \text { mths. later pre- } \\
\text { frontal leuco- } \\
\text { tomy performed }\end{array}$ \\
\hline
\end{tabular}

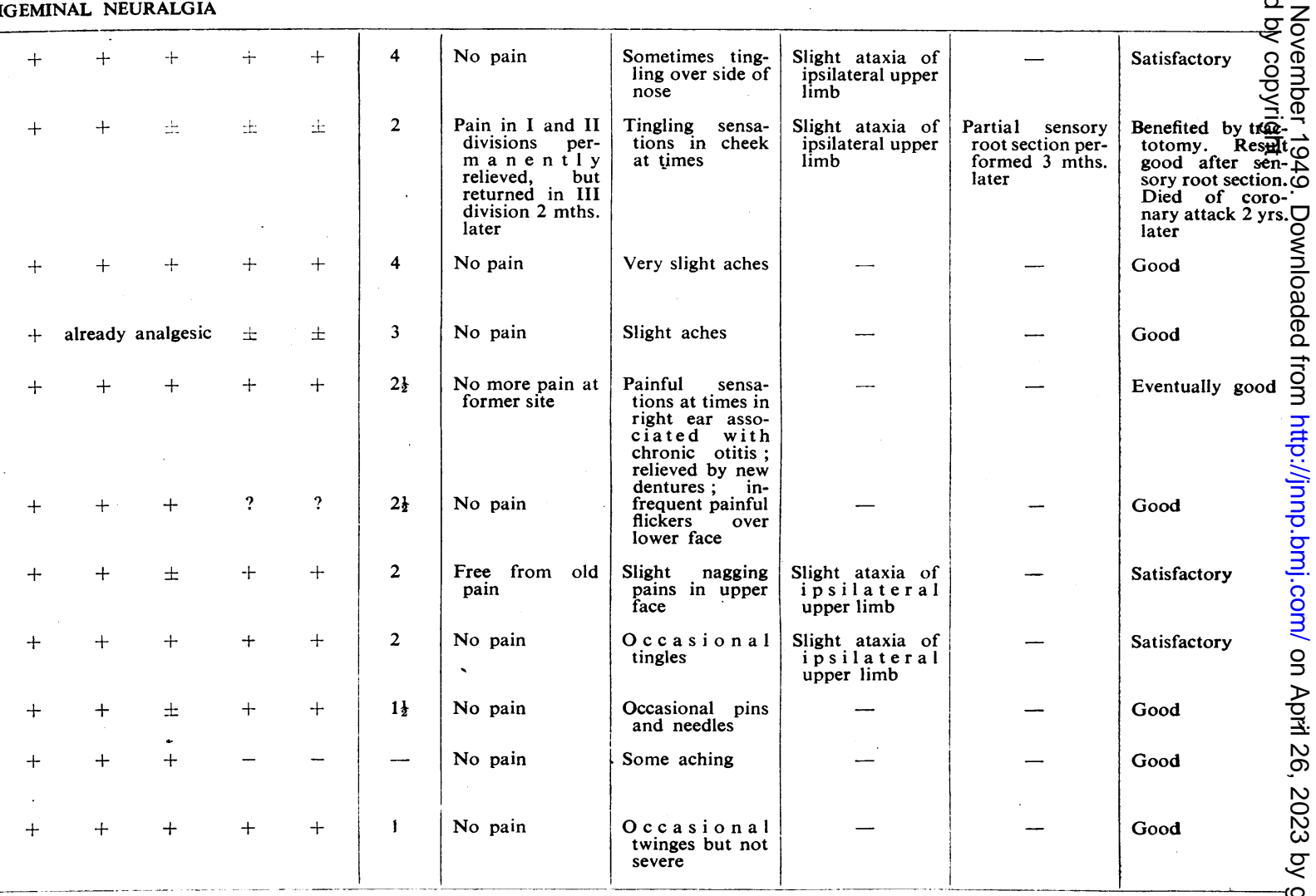




\begin{tabular}{|c|c|c|c|c|c|c|c|c|}
\hline \multirow{2}{*}{$\begin{array}{l}\text { Chrono- } \\
\text { logical } \\
\text { case } \\
\text { no. }\end{array}$} & \multirow[b]{2}{*}{$\begin{array}{l}\text { Sex ; age in years } \\
\text { referring doctor }\end{array}$} & \multicolumn{3}{|c|}{ Clinical features } & \multirow[b]{2}{*}{ Previous operations } & \multicolumn{3}{|c|}{ Particulars of traç્gtomy } \\
\hline & & $\begin{array}{l}\text { Dura- } \\
\text { tion } \\
\text { (yrs.) }\end{array}$ & $\begin{array}{l}\text { Intensity } \\
\text { of pain }\end{array}$ & $\begin{array}{l}\text { Division } \\
\text { affected }\end{array}$ & & $\begin{array}{c}\text { Level of } \\
\text { tractotomy } \\
\text { above or below } \\
\text { obex }\end{array}$ & 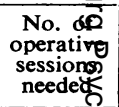 & $\begin{array}{c}\text { Complica } \\
\text { tions }\end{array}$ \\
\hline 15 & Dr. G. Rich 50 & 5 & Severe & III & $\begin{array}{l}\text { Several alcohol injections, and intra- } \\
\text { cranial section of III division } 3 \text { yrs. } \\
\text { before }\end{array}$ & $\begin{array}{l}\text { Two cuts : } 2 \text { mm. } \\
\text { and } 4 \mathrm{~mm} \text {. below }\end{array}$ & 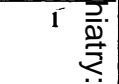 & - \\
\hline . & Readmission $1 \frac{1}{2}$ yrs. later & $\begin{array}{r}1 \frac{1}{3} \\
-\end{array}$ & Severe & $\begin{array}{l}\text { II on } \\
\text { opposite } \\
\text { side }\end{array}$ & $\begin{array}{l}\text { Alcohol injection of II division } \\
15 \text { mths. before }\end{array}$ & $3 \mathrm{~mm}$. below & 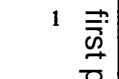 & - \\
\hline 20 & $\begin{array}{c}\text { M. } 63 \\
\text { Dr. E. McLaglan }\end{array}$ & 12 & Severe & II & $\begin{array}{l}\text { Alcohol injection of contralateral } \\
\text { Gasserian ganglion for tic douleureux } \\
\text { on opposite side of face } 1 \text { yr. before. } \\
\text { Relieved }\end{array}$ & $\begin{array}{l}\text { Three cuts : } 2 \mathrm{~mm} . \\
4 \mathrm{~mm} ., \text { and } 6 \mathrm{~mm} \text {. } \\
\text { below }\end{array}$ & $2 \frac{\bar{\sigma}}{\frac{\bar{\sigma}}{\bar{D}}}$ & - \\
\hline
\end{tabular}

E. CASE OF FACIOZ CAUSALG

\begin{tabular}{c|c|c|c|c|c}
\hline 18 & $\begin{array}{r}\text { F. 70 } \\
\text { Dr. G. Barnett }\end{array}$ & 20 & Severe & I, II & $\begin{array}{c}\text { Alcoh } \\
\text { supra } \\
\text { nerves } \\
\text { vated }\end{array}$ \\
\hline
\end{tabular}

pleased with the results of operation. Some had had their pain for many years, and most had had other operative procedures performed but pain had recurred. All patients, however, sometimes only after they had been questioned specifically, reported that they still experienced some unpleasant sensations in the analgesic area, particularly in the form of pins-and-needles, tingling pains, or itching sensations. None, however, seemed upset by these persisting paræsthesias. Comparable paræsthesias are seen in a large proportion of patients after a partial sensory root section.

The two cases of bilateral trigeminal neuralgia were also benefited. In one (Case 15) the operation was performed in two sessions spaced one and a half years apart, and this patient was restored to her full life without any ataxia. The other (Case 20), a chronic tabetic, had the operation performed on the second side because he had already undergone an alcohol injection of the Gasserian ganglion which had completely denervated the first side. Since the tractotomy on the second side he has been free from pain and has not experienced those difficulties in eating and talking which characterise bilateral alcohol injections of the Gasserian ganglion.

In two other cases of trigeminal neuralgia, the first two cases in my series, a complete section of the sensory root had been performed several years before and had been followed by persistent and severe pain in the anæsthetic area. Such cases fortunately are not common, but they occur in every neurosurgeon's experience (Olivecrona, 1939 ; Grant, 1938, 1948 ; and others). They are very intractable, and it was the distressing condition of my first patient that led me to try this procedure. Four and a half years later both patients saids they were improved, although both continued to cunglain of pain. At the time of operation it proved gifficult, because of the pre-existing facial analg\&s?, to ascertain whether the descending tracts $h \vec{g} \mathrm{~d}$-been severed or not. The only guide available to낭 was pain in the face at the moment of the incisoin and in the light of my subsequent experiences operation I wonder how complete technicisldy the operation in these two cases really was.

In Other Conditions. - I have tried the operation in two other groups of conditions, postherpetic neuralgia and causalgia of the face secondar to a lupous ulcer of the nose for which many fostic procedures had been carried out. No case was benefited, and some indeed were made orse. Three of the four cases of postherpetic neufralgia were temporarily relieved from pain, but 9 the three surviving cases pain returned as severely as ever. One case has since been benefited byọ prefrontal leucotomy, and this case has already been reported in detail (Falconer, 1947). He re benefited nearly three years after this lattes-procedure. Sjöqvist $(1938$ b) had reported failure of the operation to relieve pain in one case of herpetic neuralgia.

I have not yet had the opportunity of trying this operation for the relief of facial pain occasioned by malignant disease. Grant (Grant and Weinborger, 1941 ; Grant, 1943) has reported several succèssful cases. Also I have not had experience. in the treatment of glossopharyngeal pain by this opera- 
intinued

IGEMINAL NEURALGIA

\begin{tabular}{|c|c|c|c|c|c|c|c|c|c|c|}
\hline \multicolumn{5}{|c|}{$\begin{array}{l}\text { Distribution and grade of analgesia } \\
\text { after tractotomy }\end{array}$} & \multirow{2}{*}{$\begin{array}{c}\text { Period } \\
\text { of } \\
\text { follow- } \\
\text { up after } \\
\text { tracto- } \\
\text { tomy } \\
\text { (yrs.) }\end{array}$} & \multicolumn{4}{|c|}{ Follow̄-up results } & \multirow{2}{*}{$\begin{array}{l}\text { General impression } \\
\text { of end-result }\end{array}$} \\
\hline $\begin{array}{l}\text { igeminal } \\
\text { I }\end{array}$ & nerve & $\begin{array}{l}\text { division } \\
\text { III }\end{array}$ & $\begin{array}{l}\text { 9th } \\
\text { cranial } \\
\text { nerve }\end{array}$ & $\begin{array}{l}\text { 10th } \\
\text { cranial } \\
\text { nerve }\end{array}$ & & $\begin{array}{l}\text { Persistent or } \\
\text { recurrent pain }\end{array}$ & $\begin{array}{c}\text { Parzsthesias } \\
\text { of face }\end{array}$ & $\begin{array}{c}\text { Other neurological } \\
\text { sequelæ }\end{array}$ & $\begin{array}{c}\text { Further operative } \\
\text { procedures } \\
\text { required }\end{array}$ & \\
\hline$\therefore$ & + & + & + & \pm &.$^{2}$ & $\begin{array}{l}\text { Pain relieved on } \\
\text { that side }\end{array}$ & Slight tingling & - & - & Good \\
\hline+ & + & + & + & + & $\frac{1}{4}$ & $\begin{array}{l}\text { Pain relieved on } \\
\text { second side }\end{array}$ & Slight tingling & - & - & Good \\
\hline+ & + & + & + & + & $\frac{1}{3}$ & No pain & Slight aching & $\begin{array}{l}\text { Slight increase of } \\
\text { ataxia in ipsi- } \\
\text { lateral upper } \\
\text { limb }\end{array}$ & - & $\begin{array}{l}\text { Satisfactory result } \\
\text { in a tabetic }\end{array}$ \\
\hline
\end{tabular}

IONDARY TO LUPUS VULGARIS

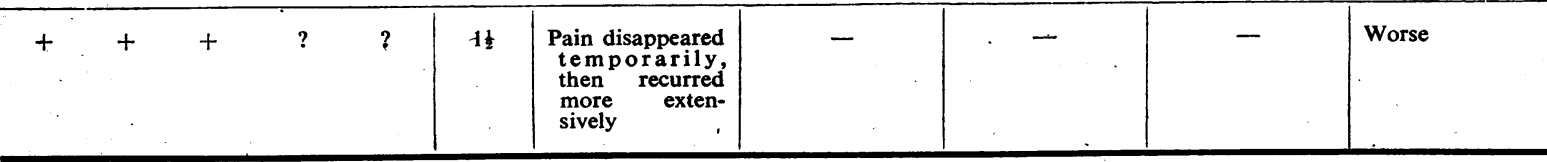

tion. The fact that the operation will produce analgesia in the territory of the glossopharyngeal nerve suggests that, by itself, it might prove effective in painful conditions in the tonsillar fossa, pharynx, and hinder part of the tongue. Probably it would be wiser in painful conditions due to malignant disease affecting the pharynx to combine the procedure with an intracranial section of the glossopharyngeal nerve, as Grant (1943) has advised.

Trigeminal tractotomy has also been tried by Olivecrona (1947) for the treatment of migraine. Eight out of thirteen cases in his series appear to have been benefited. Olivecrona, however, concludes his article by drawing attention to Gardner's (Gardner and others, 1947) procedure for migraine - of division of the greater superficial petrosal nerve, and reports two successful cases. In this neurosurgical clinic we have since tried Gardner's procedure in a number of cases, usually with gratifying results. I have therefore not had occasion to try. tractotomy for migraine.

\section{Conclusions : Indication for Operation}

From personal experience I would say that there are three main indications for intramedullary trigeminal tractotomy. They are : (1) cases of first and also possibly second division trigeminal neuralgia (tic douloureux); (2) cases of bilateral trigeminal neuralgia (tic douloureux); (3) cases of persistent pain following complete sensory root section performed for trigeminal neuralgia:

To these indications can probably be added a fourth: intractable facial pain secondary to malignant disease.' As I have not had experience of it I shall not discuss this indication further.

First and Second Division Trigeminal Neuralgia.For cases of trigeminal neuralgia involving the third or second divisions of the nerve (which comprise most cases of tic douloureux) the operation of partial section of the sensory root of the Gasserian ganglion, sufficient fibres being left in the inner part of the root to preserve sensation in the forehead and cornea, is a satisfactory procedure. Moreover it is well standardized and carries little risk to life. It is likely to remain the routine procedure for these cases.

The therapeutic problem, however, is altered when first-division neuralgia is considered, for if sensory root section is employed in these cases the cornea is inevitably denervated at the same time as the forehead, while if lesser procedures are used, such as avulsion of the supraorbital and supratrochlear nerves, the chances of persistent or recurrent symptoms are considerable. An insensitive cornea is to be avoided, as it is apt to be followed by neuropathic keratitis, especially when a temporary facial palsy is also present, as not uncommonly occurs after sensory root section.

More and more I am coming to the view that for first-division trigeminal neuralgia; trigeminal tractotomy is the procedure of election. The same conclusion probably also holds true for those cases of second division neuralgia where the pain is located close to the eyeball or secondarily spreads to the first division, for it is usually impossible to relieve these cases of their periorbital and forehead 
pain by graduated sensory root section without denervating the cornea (see Cases 8 and 15 in the Table). Fortunately the first two divisions are the ones most readily denervated by the intramedullary operation, and they can usually be rendered analgesic without the appearance of permanent ataxia from interference with the restiform body. As touch is preserved in the cornea, there is no risk of neuropathic keratitis, nor is there any risk of facial palsy.

Bilateral Trigeminal Neuralgia.-Fortunately this is not common, but hitherto when it has occurred it has been a very difficult therapeutic problem. A patient with complete loss of sensation over the lower part of his face on both sides is to be pitied, for he loses postural sensibility in his lower jaw and can eat only when he looks at his mouth in a mirror or touches his jaw with his hand. The lot of the patient who has also an associated bilateral masticatory weakness is miserable in the extreme, for he can only eat when he holds and moves his lower jaw with his hand.

Fortunately both these distressing states are avoided by trigeminal tractotomy, for after this operation touch is preserved and there is no disturbance of postural sensibility in the jaw, nor any risk of a masticatory paralysis. Of course most patients who develop pain on the second side, have already had the first side operated on some time previously. However, it does not matter much whether the first side is completely denervated or not, provided the lower part of the face on the second side is not denervated completely also. Olivecrona (1942) has previously mentioned this indication for trigeminal tractotomy, and has even reported a case in which he operated on both sides at one session. My own two cases confirm his report that trigeminal tractotomy can be a satisfactory procedure for bilateral trigeminal neuralgia.

Persistent Pain after Sensory Root Section for Trigeminal Neuralgia.-After a partial section of the sensory root of the Gasserian ganglion, the pain of trigeminal neuralgia may sometimes appear in a part of the face above the denervated area. These cases can then be treated on their merits, either by an operation to extend the section of the sensory root, or by intramedullary tractotomy. They need not be considered further here.

A different problem is the "syndrome of painful anæsthesia" which supervenes in about 3 to 4 per cent. of cases after sensory root section. After a variable period of relief from all pain, these patients develop. within the anæsthetic area pain of an incessant dull and often burning character. This pain steadily increases, and before long these unfortunate patients complain as bitterly of theor new pain as they did of their old. Grant (193\%) and Olivecrona (1939) have both drawn attention to this syndrome, and to the futility of such procedures as further section of the sensory roop thoraco-cervical sympathectomy, and stripping of the carotid artery. Olivecrona (1939) also reportend having tried tractotomy in these cases but without success.

It was in therapeutic desperation that I perform my first tractotomies in two typical cases of the syndrome. Both were benefited by lessening their pain, and this benefit was maintained for several years. If again confronted by this probleng I would again try the same procedure. It difficult in such patients to tell how completely the descending trigeminal tract has been sectioned, for the face is already analgesic from the previous operation. Guides are afforded, however, by the amount of pain felt by the patient when the tract actually being sectioned, and also by the appearance of analgesia in areas outside the trigeminal territor $\overrightarrow{0}$ It is interesting that in both my cases pain was produced in the face when the tract was beging sectioned, because theoretically the tract shoplo have degenerated as a result of the complete foot section performed years before. Perhaps these por sections had not been as complete as was imagife

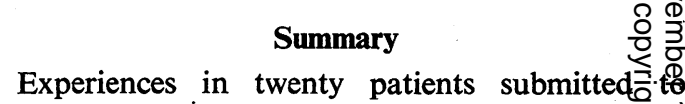
section of the descending tract of the trigempd nerve, and the anatomical principles and techniqueto of the operation, are described. It is recommended that the tract be divided at a level below the lowe angle of the fourth ventricle, and that the section be carried out under local anæsthesia, so that resulting sensory loss in the face can be tested and the extent of the incision controlled. A method of confirming the situation of the tract before section by pricking the medulla with a needle is described. $\frac{3}{\sqrt{2}}$

This operative procedure produces loss of pa而 and temperature sensibility, but with sparing of tactile sensibility, in the skin and mucous surfaces supplied by the trigeminal, facial, glosso-pharynged and vagus nerves. This loss is usually permanen? There is no risk of neuropathic keratitis, facigh palsy, or of masticatory paralysis, complicatio which are not infrequently seen after section of the sensory root of the Gasserian ganglion. Tie complication most often seen after tractotomy slight ataxia of the ipsilateral upper limb, but wi care this can usually be avoided. Such complica tions as laryngeal palsy, gross ataxia, and loss of postural sensibility in the ipsilateral limbs will nf occur if the incision is correctly placed. 
The chief indications for the operation are seen in cases of trigeminal neuralgia involving the first division of the trigeminal nerve, in cases of bilateral trigeminal neuralgia where an operative procedure has to be carried out on the second side, and in cases of severe persistent pain following a previous sensory root section. The procedure is also indicated in some cases of intractable pain due to malignant disease. It is not beneficial in postherpetic neuralgia.

In the author's experience intramedullary trigeminal tractotomy has passed from being an operation which is still in the experimental stage to being an operation the technique and indications for which have become standardized.

My thanks are due to Miss Evelyn Madigan for technical assistance in the preparation of this paper, and to the various physicians and surgeons who have entrusted me with their patients. With the exception of one patient, operated on in the Radcliffe Infirmary, Oxford, England, through the courtesy of Professor Sir Hugh Cairns, all patients in the series have been operated on in the Dunedin Hospital, New Zealand. I am also grateful to Professor $\mathbf{H}$. Olivecrona and to Drs. F. C. Grant and L. M. Weinberger for permission to reproduce diagrams from their papers.
REFERENCES

Brodal, A. (1947). Arch. Neurol. Psychiat., Chicago, 57, 292.

Falconer, M. A. (1947). Proc. Assoc. Res. nerv. ment. Dis., 27, 706.

Finlayson, A. I., and Penfield, W. (1941). Arch. Neurol. Psychiat., Chicago, 46, 250.

Gardner, W. J., Stowell, A., and Dutlinger, R. (1947). J. Neurosurg., 4, 105.

Grant, F. C. (1938). Ann. Surg., 107, 14

(1943). Bull. N.Y. Acad. Med., 19, 373.

(1948). Amer. J. Surg., 75, 42.

, Groff, R. A., and Lewy, F. H. (1940). Arch. Neurol. Psychiat., Chicago, 43, 498.

and Weinberger, L. M. (1941 a). Arch. Surg., 42, 681 .

- (1941 b). Surg. Gynec. Obstet., 72, 747.

Jackson, H., and Ironside, R. (1939). Proc. R. Soc. Med., 32, 219.

Olivecrona, H. (1939). Acta chir. scand., 82, 99.

(1942). Arch. Neurol. Psychiat., Chicago, 47, 544. (1947). Acta med. scand., Suppl. 196, 229.

Rowbotham, G. F. (1938). Brit. med. J., 2, 1073. (1939). Brain, 62, 364.

Sabin, F. R. (1901). "An Atlas of the Medulla and Midbrain." Baltimore, Md.

Sjöqvist, O. (1938 a). Z Zbl. Neurochir., 2, 274.

$-(1938$ b). Acta psychiat. neurol., Suppl. 17.

Smyth, G. E. (1939). Brain, 62, 41.

Walker, A. E. (1939): J. Neurophysiol., 2, 234.

Weinberger, L. M., and Grant, F. C. (1942). Arch. Neurol. Psychiat., Chicago, 48, 355.

,- (1943). Ibid., 49, 665. 